Research, part of a Special Feature on Ecological Restoration in Northern Regions

\title{
Drivers of Ecological Restoration: Lessons from a Century of Restoration in Iceland
}

\author{
$\underline{\text { Ása L. Aradóttir }}^{1}$, Thorunn Petursdottir $^{2,3}, \underline{\text { Gudmundur Halldorsson }}^{2}$, Kristin Svavarsdottir $^{2}$ and Olafur Arnalds $^{1}$
}

\begin{abstract}
We analyzed the main drivers for ecological restoration in Iceland from 1907 to 2010 and assessed whether the drivers have changed over time and what factors might explain the changes, if any. Our study was based on a catalogue of 100 restoration projects, programs, and areas, representing $75 \%$ to $85 \%$ of all restoration activities in Iceland. Catastrophic erosion was an early driver for soil conservation and restoration efforts that still ranked high in the 2000s, reflecting the immense scale of soil erosion and desertification in Iceland. Socioeconomic drivers such as farming and the provision of wood products were strong motivators of ecological restoration over most of the 20th century, although their relative importance decreased with time as the number and diversity of drivers increased. In the 1960s and 1970s, the construction of hard infrastructure, and moral values such as improving the aesthetics of the countryside and "repaying the debt to the land" emerged as motivations for restoration actions. In the late 1990s, the United Nations Climate Change Convention became a driver for restoration, and the importance of nature conservation and recreation increased. Technological development and financial incentives did not show up as drivers of ecological restoration in our study, although there are some indications of their influence. Furthermore, policy was a minor driver, which might reflect weak policy instruments for ecological restoration and some counteractive policies.
\end{abstract}

Key Words: birch woodlands; drivers; ecological restoration; heathlands; land degradation; revegetation; soil erosion; wetlands

\section{INTRODUCTION}

Ecological restoration is driven by many interacting motivations and mechanisms. Increased ecosystem productivity is historically the main motivation of ecosystem restoration, but often does not consider other long-term ecological benefits or consequences (Hobbs and Norton 1996, Marais et al. 2007). The provision of a number of ecosystem services, such as clean water and climate amelioration, has also been a strong motivator of restoration (Clewell and Aronson 2006, Turpie et al. 2008, Suding 2011). Concerns about conservation values and biodiversity are important biotic rationales for restoration, including the preservation of rare and endangered species, biotic communities, and landscapes (Hobbs and Norton 1996, Clewell and Aronson 2006). The reversal of land degradation is another environmental motivation for ecological restoration (Hobbs and Norton 1996), often to compensate for ecosystem destruction by construction (Clewell and Aronson 2006, Suding 2011). Motivation for restoration can also be idealistic or moral, e.g., to atone for past or present environmental degradation, to reconnect with nature, or to seek spiritual renewal (see e.g., Clewell and Aronson 2006).

Mechanisms that stimulate ecological restoration can be financial or nonfinancial, or both. Financial mechanisms drive restoration projects by providing economic incentives such as private market arrangements, voluntary private nonmarket funding systems, governmentally run financial incentives, and government-supported market creation (de Groot et al. 2007). Nonfinancial mechanisms, on the other hand, involve indirect incentives, such as governmental intervention by laws and legislation, voluntary work of nongovernmental organizations (NGOs), other voluntary ecological restoration work resulting from local action, and restoration work based on aesthetic values, ethics, or faith (McGhee et al. 2007).

McGhee et al. (2007) suggested that a comprehensive inventory of restoration projects could be a valuable tool to inform decision makers and policy makers about the value of ecological restoration. We propose that such an inventory could also be used to analyze the factors driving ecological restoration. We compiled a review of ecological restoration in Iceland (Aradóttir and Halldórsson 2011) in relation to an analysis of the extent, status, methods, and results of restoration activities in the Nordic countries (Halldórsson et al. 2012). The history of organized soil conservation and restoration work in Iceland now spans more than a century (Crofts 2011). Thus, our review provided an opportunity to identify the factors driving restoration over a long period of time that involves profound changes in socioeconomic conditions and scientific understanding, as well as changes in national and international environmental policy. In this paper, we aim to analyze the history of ecological restoration in Iceland, with a focus on what has driven it. We also ask whether drivers for restoration have changed over time and, if so, what factors might explain the changes.

\section{BACKGROUND: DISTURBANCES AND LAND DEGRADATION IN ICELAND}

Iceland, one of the most active volcanic regions on Earth (Thordarson and Höskuldsson 2008), has undergone severe

${ }^{1}$ Faculty of Environmental Sciences, Agricultural University of Iceland, ${ }^{2}$ Soil Conservation Service of Iceland, ${ }^{3}$ Institute for Environment and Sustainability (IES), European Commission, Joint Research Centre (JRC) 
ecosystem degradation and desertification over the millennia since the Norse settlement (Amorosi et al. 1997, Arnalds et al. 2001, Dugmore et al. 2009). An important contributing factor is heavy utilization of its fragile subarctic to boreal ecosystems, primarily by extensive clear-cutting of natural woodlands and livestock grazing (Gísladóttir et al. 2010). This led to direct degradation and reduced resilience to natural disturbances such as volcanic ash deposition, long-lasting periods of unfavorable climatic conditions, and flooding (Aradottir and Arnalds 2001, Greipsson 2012).

About $42 \%$ of Iceland is a desert with limited vegetation cover (Table 1). The dominant soil type is Andosol, with organic Histosols occupying some wetland areas, but the deserts have sandy soils (Arnalds 2008). Severe erosion problems still exist, with considerable to very severe erosion occurring on about $50 \%$ of the country, and continuing land degradation problems (Arnalds et al. 2001). Extensive areas that still have vegetation cover are degraded and have reduced soil organic carbon and nutrient pools (Óskarsson et al. 2004). Not all desert surfaces of Iceland are anthropogenic; some are formed by volcanic eruptions and flooding, and many desert areas at high elevations are above the natural vegetation limits.

Table 1. Vegetation and other main surface types of Iceland, summarized by elevation belts. Based on the AUI Farmland Database (Nytjaland; http://groa.rala.is/Kortavefsja/default. aspx), simplified from Arnalds (2011). Areas are given in $\mathrm{km}^{2}$.

\begin{tabular}{lccccc}
\hline \hline & \multicolumn{3}{c}{ m above sea level } & & \\
\cline { 2 - 4 } Cover & $0-400$ & $400-800$ & $>800$ & Total & $\begin{array}{c}\% \text { of } \\
\text { Iceland }\end{array}$ \\
\hline Vegetated & 31,194 & 14,509 & 470 & 46,173 & 44.8 \\
Birch woodland/ & 1194 & 11 & & 1205 & 1.2 \\
shrubland & & & & & \\
Grassland & 2209 & 165 & 1 & 2375 & 2.3 \\
Heathland & 19,393 & 11,839 & 458 & 31,690 & 30.8 \\
Wetland & 4346 & 1449 & 2 & 5797 & 5.6 \\
Other vegetated & 4052 & 1045 & 9 & 5106 & 4.9 \\
Poorly vegetated/ & 10,284 & 24,576 & 8556 & 43,416 & 42.2 \\
barren & & & & & \\
Glaciers & 267 & 1147 & 9687 & 11,101 & 10.8 \\
Rivers / Lakes & 1513 & 648 & 69 & 2230 & 2.2 \\
Total & 43,258 & 40,880 & 18,782 & 102,920 & 100 \\
\hline
\end{tabular}

Most of Iceland has been grazed by sheep since the Norse settlement. The grazing practices used to include winter and spring grazing, which had very damaging effects on ecosystems. Overgrazing has been a common problem and continues to be so in places, although winter and spring grazing have mostly been discontinued since the 1970s (Arnalds and Barkarson 2003).

From the 1940s until the late 1980s, extensive wetlands were drained for agricultural production, mostly for improving fields for haymaking and grazing, resulting in about 32,000 $\mathrm{km}$ of ditches, draining $50 \%$ to $75 \%$ of Icelandic wetlands
(Óskarsson 1998). It has been estimated that this contributes to an immense release of greenhouse gases, equaling all the burning of fossil fuels in the country on a yearly basis (Hallsdóttir et al. 2010).

Other disturbances include road construction, with about $13,000 \mathrm{~km}$ of roads in rural Iceland, and over 3000 registered gravel mines (ICERA 2012). The construction of hydropower plants has disturbed many watersheds, with concomitant submersion of ecosystems by reservoirs. Likewise, geothermal power plants cause localized disturbances, e.g., in the form of drilling platforms and pipelines. More recently, urbanization of the Icelandic population (FAI 2009) is claiming increased land areas, and rapidly growing tourism is increasing pressure in vulnerable areas.

\section{METHODS}

\section{Cataloging ecological restoration in Iceland}

For the review of ecological restoration in Iceland, we asked public agencies, private companies, nongovernmental organizations (NGOs), municipalities, and other known or potential actors of restoration in the country (with the exception of private individuals) to provide information about their past and ongoing restoration projects. We contacted all directly, and held meetings with their representatives, as well as administrators and members of the scientific community. Not all of these parties were responsible for restoration projects, but those 10 actors who were responsible provided a short summary about their restoration activities, based on a standardized template. This included a short historical overview of their activities and their context, an overview table of restoration areas/projects, a self-assessment by agencies and actors of the outcome of restoration projects, and a list of published materials, where applicable.

The data provided information on when the restoration work started, the extent of the area, types of interventions, main objectives, and cooperative parties. We encouraged the actors to include photographs of the restoration activities, including "before" and "after" photos when available, and additional relevant information. An editorial group of restoration experts, representing a wide-ranging knowledge of restoration in Iceland, reviewed the contributions and selected which areas/ projects to include. The Society for Ecological Restoration International Science \& Policy Working Group (SER) definition of ecological restoration and its nine attributes of restored ecosystems, described in The SER International Primer on Ecological Restoration (SER 2004), were used as a guide for the selection. Ecological restoration is a long-term process and many areas and projects did not fulfill all the nine attributes. A minimum requirement was set that the interventions had to be based on approaches that were likely to result in a trajectory toward native ecosystems, such as heathlands, birch woodlands, or wetlands, based on past 
Table 2. Main actors, number, and extent of ecological restoration areas in Iceland, 1907-2010. Two large-scale ecological restoration programs Hekluskógar and Farmers Heal the Land are not included in the table (see explanations in text).

\begin{tabular}{|c|c|c|c|c|c|c|}
\hline \multicolumn{2}{|c|}{ Actors (main responsibility) } & \multicolumn{3}{|c|}{ Habitat (no. of areas) } & \multirow{2}{*}{$\begin{array}{c}\text { Total of } \\
\text { areas }\end{array}$} & \multirow[t]{2}{*}{ Size $\left(\mathrm{km}^{2}\right)$} \\
\hline & & $\begin{array}{l}\text { Heathland } \\
\text { /grassland }\end{array}$ & Woodland & Wetland & & \\
\hline \multirow[t]{5}{*}{ Public bodies } & Soil Conservation Service of Iceland (SCSI) & 26 & & 1 & 27 & $1438.5^{\dagger}$ \\
\hline & Forest Service (IFS) & & 26 & 1 & 27 & 186.3 \\
\hline & Iceland Road Administration & & & $7^{\ddagger}$ & 7 & 2.2 \\
\hline & Wetland Committee & & & $10^{\ddagger}$ & 10 & 2.5 \\
\hline & N-Iceland, Regional Afforestation Project & & 2 & & 2 & 1.8 \\
\hline \multirow[t]{2}{*}{ Energy companies } & Landsvirkjun & $7^{\S}$ & 1 & & 8 & 146.5 \\
\hline & Orkuveita Reykjavíkur & 3 & 1 & & 4 & 11.4 \\
\hline NGOs & Gróður fyrir fólk & 11 & & & 11 & 1.3 \\
\hline Sum & & 47 & 30 & 19 & 96 & \\
\hline Area $\left(\mathrm{km}^{2}\right)$ & & 1573.1 & 191.7 & 25.7 & & 1790.5 \\
\hline
\end{tabular}

The SCSI only reported on restoration areas $10 \mathrm{~km}^{2}$ or larger.

${ }^{\ddagger}$ Many of these projects were jointly implemented by the Iceland Road Administration and the Wetland Committee; in some cases involving local landowners and NGOs.

${ }^{\S}$ Most of Landsvirkjun’s heathland/grassland restoration projects were carried out in close co-operation with SCSI.

research (e.g., Gunnlaugsdottir 1985, Gretarsdottir et al. 2004). This excluded areas that were dominated by, or were likely to become dominated by, exotic species, such as those seeded with Nootka Lupine (Lupinus nootkatensis) or planted with exotic tree species.

The review was published in Icelandic and contained 40 chapters, written by 35 authors (Aradóttir and Halldórsson 2011). In addition to the summary of restoration activities, it contained a catalogue of known current and past ecological restoration research projects in Iceland, giving information about their aims, project leaders, and institutions involved, together with a list of publications from each one. The review also included background information about land degradation and other disturbances, the history of ecological restoration, information about ecological restoration education and outreach activities, and a policy framework review. The policy review was based on a systematic search of all active laws and regulations that could potentially apply to ecological restoration and on relevant policy documents issued by governmental agencies and ministries.

\section{Analyzing drivers of restoration}

The motivation for most restoration areas and projects was described by the responsible actors in the review document (Aradóttir and Halldórsson 2011). In some cases, the motivation had already been described in original project descriptions of the Soil Conservation Service of Iceland (SCSI, unpublished reports) or other related documents. However, such information did not exist for many areas and projects established decades ago, and hence the responsible agencies were asked to give their evaluation of the main motivations for these areas and projects. Based on this information, the main drivers for each restoration area and project and their order of importance were determined for each of four periods: 1907 through the 1930s, 1940s through the 1960 s, 1970s and 1980s, and the 1990s to the present. These periods were based on revegetation periods defined by Magnússon (1997), but with some adjustments. The drivers were broadly categorized into environmental drivers, socioeconomic drivers, law and policy drivers, and other drivers, and subcategories were added as needed. The most important driver was given the score 3 , the second most important driver the score 2 and so on; totaling a maximum sum of 6 for each restoration area or project within each period. We categorized the ecological restoration areas by their prevalent habitat type and calculated the average score for each driver within habitat type and period. Because the scoring was value based, we did not analyze the data any further and we present the results without units.

\section{RESULTS}

\section{Overview of ecological restoration in Iceland}

The review of ecological restoration in Iceland included 96 restoration areas, covering nearly $1800 \mathrm{~km}^{2}$ (Table 2). The review included two large-scale restoration programs not included in Table 2: Farmers Heal the Land (FHL) and Hekluskógar. FHL is a cost-share program, organized by the Soil Conservation Service of Iceland (SCSI), and covered about $150 \mathrm{~km}^{2}$ of restoration areas in 2010 (Petursdóttir 2011). It involves around 600 farmers who carry out revegetation of severely degraded areas on their own land, but the SCSI provides fertilizer, extension services, and seed where needed. Hekluskógar is a recent program that aims to restore native woodlands and shrublands on more than $900 \mathrm{~km}^{2}$ in the vicinity of the Mount Hekla volcano, but restoration actions have so 
far only been implemented on a part of this area (Óskarsson 2011a).

The SCSI was by far the largest actor of ecological restoration in Iceland, with 27 restoration areas covering $1438 \mathrm{~km}^{2}$ (Halldórsson et al. 2011). The agency only reported on restoration areas larger than $10 \mathrm{~km}^{2}$, which comprise nearly $80 \%$ of its restoration activities (SCSI unpublished data). Other actors were responsible for about $350 \mathrm{~km}^{2}$ of restoration areas (Table 2). Our review did not include restoration by private landowners, except when it was related to restoration by agencies or to specific funding schemes, but we estimate this to be less than $100 \mathrm{~km}^{2}$. Taking into account the $150 \mathrm{~km}^{2}$ restored within FHL, the total extent of restored areas or areas undergoing restoration in Iceland was at least $2300 \mathrm{~km}^{2}, 2.5 \%$ of the country, excluding glaciers. Thus, we estimate that our review covered $75 \%$ to $85 \%$ of restored areas in Iceland.

Heathland and grassland were the most extensively restored habitats (Table 2), mostly restored by revegetation or reclamation of eroded or other severely degraded land. The difference between habitats was, however, not always clearcut, as birch woodlands have later started to colonize some of the revegetated areas, and small wetlands may be formed in areas with a high water table. Most of the heathland/grassland projects were over $10 \mathrm{~km}^{2}$ (Table 3 ). The SCSI was the main actor in heathland/grassland restoration (Table 2). Landsvirkjun, the largest energy company operating in the country, also contributed substantially toward ecological restoration of these habitats, but its restoration projects were often organized and carried out in cooperation with the SCSI (Gunnarsdóttir and Aðalsteinsson 2011). An NGO, Gróður fyrir fólk, reported on a number of small projects in these habitats that primarily used organic residues from horse stables in the capital region and from some other sources for revegetation of eroded or severely disturbed sites (Jónsson 2011).

The Icelandic Forest Service (IFS) was the largest actor in woodland restoration aimed at restoring native birch woodlands (Table 2; Eysteinsson 2011). This type of restoration was often passive, i.e., based on protection from livestock grazing, thus providing an opportunity for natural colonization of birch. In other cases, the restoration was assisted by revegetation or other actions to promote birch establishment. The majority of the woodland restoration areas were small, under $10 \mathrm{~km}^{2}$ (Table 3). The energy companies were also active in small-scale woodland restoration (Table 2; Gunnarsdóttir and Ađalsteinsson 2011). Regional afforestation programs, which are currently the major actors in tree planting in Iceland, only reported on two small woodland restoration projects (Table 2; Thórsson 2011), but most of their operations are based on silviculture with nonnative tree species (Eysteinsson 2004).
Table 3. Size distribution of ecological restoration areas excluding two large-scale ecological restoration programs Hekluskógar and Farmers Heal the Land (see details in text).

\begin{tabular}{llcccc}
\hline \hline \multirow{2}{*}{ Habitats } & & \multicolumn{4}{c}{ Number of areas in each size class ${ }^{\dagger}$} \\
\cline { 3 - 6 } & Actors & $\begin{array}{c}<1 \\
\mathrm{~km}^{2}\end{array}$ & $\begin{array}{c}1-10 \\
\mathrm{~km}^{2}\end{array}$ & $\begin{array}{c}10-100 \\
\mathrm{~km}^{2}\end{array}$ & $\begin{array}{c}>100 \\
\mathrm{~km}^{2}\end{array}$ \\
\hline Birch woodland & Public & 8 & 15 & 5 & 0 \\
& $\begin{array}{l}\text { Energy } \\
\text { companies }\end{array}$ & 0 & 2 & 0 & 0 \\
Heathland/grassland & $\begin{array}{l}\text { Public } \\
\text { NGOs }\end{array}$ & 0 & 0 & 25 & 1 \\
& $\begin{array}{l}\text { Energy } \\
\text { companies }\end{array}$ & 2 & 4 & 4 & 0 \\
Wetland (incl. & Public & 18 & 0 & 1 & 0 \\
streams and lakes) & & 39 & 21 & 35 & 1 \\
Total no. of areas & & & & & 0 \\
\hline
\end{tabular}

The SCSI only reported on ecological restoration areas $10 \mathrm{~km}^{2}$ or larger.

A designated committee, formed by the Ministry of Agriculture in 1996, was responsible for initiating a number of wetland restoration projects between 1996 and 2003 (Garðarsson et al. 2006, Óskarsson 2011b), many of which were implemented jointly with the Icelandic Road Administration (Table 2). Wetland restoration most often involved the filling up of drainage ditches or installing small dams to restore mires, fens, or small lakes that were mostly less than $1 \mathrm{~km}^{2}$ (Table 3). However, one large $\left(>10 \mathrm{~km}^{2}\right)$ wetland area was formed after the revegetation of a floodplain area with a high water table, previously covered with entirely barren sand (Runólfsson et al. 2009).

In addition to the restoration areas and programs detailed above, two projects dealing with restoration of animal populations or their habitat are included in the review: the Icelandic population of the White-tailed Eagle (Haliaeetus albicilla) population (Skarphéðinsson 2011) and the brown trout (Salmo trutta) population of Lake Thingvallavatn (Gunnarsdóttir and Aðalsteinsson 2011).

We also catalogued 70 research projects on restoration (Aradóttir et al. 2011). The oldest one started in 1946, but the number of projects increased sharply toward the end of the 20th century (Fig. 1A). The results of these research projects were presented in over 220 publications, of which nearly twothirds were published in "gray literature," i.e., reports and other non-peer-reviewed publications (Fig. 1B).

\section{Drivers of ecological restoration}

The number of drivers increased with time in both birch woodland and heathland, from four in the first period (1907 to 1930s) to nine in the last one (after 1990), and some drivers remained important in all periods (Fig. 2). The drivers also differed among habitats. Halting of soil erosion and protection of vegetation and soils were the strongest environmental 
Fig. 1. (A) Number of new research projects related to ecological restoration in Iceland, starting in each decade and (B) associated publications until 2010. No research projects related to restoration or revegetation are known before 1940.

(A)

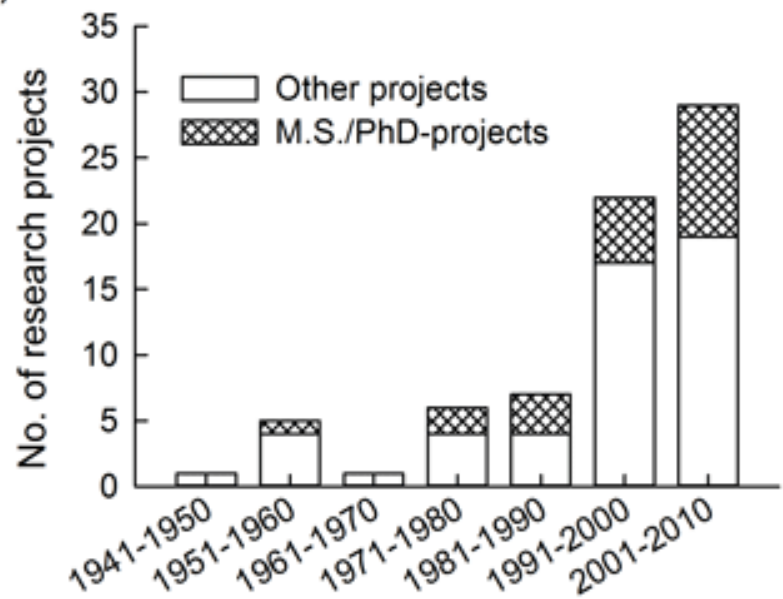

(B)

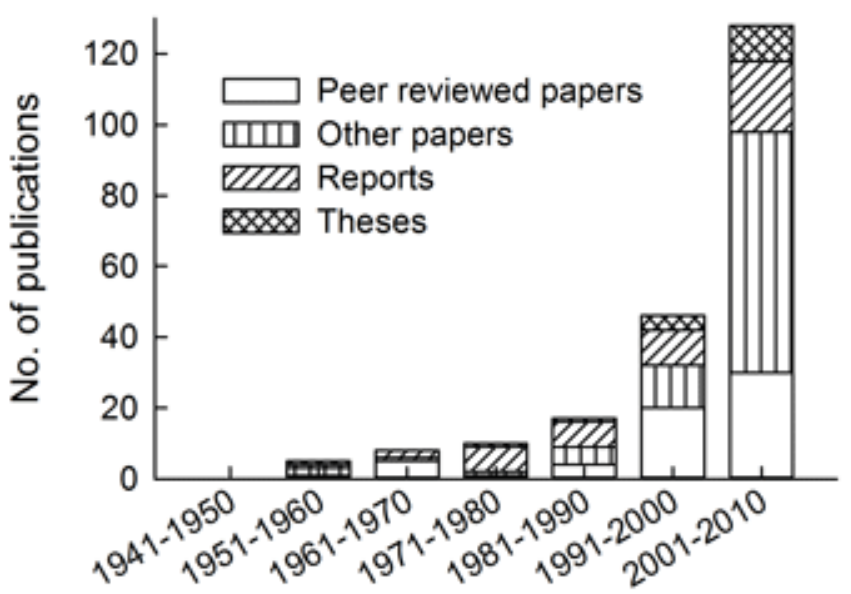

drivers for heathland/grassland restoration throughout the 20th century. For woodland restoration, nature conservation and ecological restoration were the strongest environmental drivers. Those drivers also applied to the restoration of wetlands, lakes, and streams, once this commenced in the 1990s. The provision of wood and grazing land were important socioeconomic drivers for woodland and heathland/grassland restoration, respectively, although their relative importance decreased with time. In the 1970s, other socioeconomic drivers, such as mitigation associated with the construction of hard infrastructure (roads and power plants), came into play, and their importance increased after 1990, when there was a noticeable shift in the number and diversity of factors driving restoration (Fig. 2).

New drivers in the 1990s included mitigation of the effects of tephra deposition by volcanic eruptions and reduction of atmospheric greenhouse gases by carbon sequestration in vegetation and soils as a part of the governmental policy to comply with the United Nations Framework Convention in Climate Change (UNFCCC) commitments; the latter was categorized as both a policy and environmental driver. On the other hand, conservation of biodiversity, per se, was rarely included as an important driver. Furthermore, law and policy did not show up as strong drivers of ecological restoration in our analysis, although they were among the listed drivers of heathland restoration in the 1907 through 1930s and 1970s through the 1980s (Fig. 2). The first period coincides with the passage of the 1907 Act on Forestry and Protection against Soil Erosion, and the second period coincides with a parliamentary resolution allowing for increased funds for land reclamation and land conservation in 1974 (Table 4). Other recorded drivers include moral drivers such as romantic ideas about restoring past ecological riches ("paying the debt to the land") and preserving native birch woodlands, which were strong drivers in woodland restoration throughout the study period.

\section{DISCUSSION}

\section{Changes in drivers of ecological restoration, 1907 to 2010}

Deforestation, soil erosion, and declining agricultural production motivated conservation actions in different parts of the world in the late 19th and early 20th centuries (reviewed by Galatowitsch 2012). In Iceland, a law on vegetation and soil conservation that marked the beginning of organized work leading to ecological restoration and to the establishment of agencies that later became the Soil Conservation Service of Iceland (SCSI) and the Icelandic Forest Service (IFS), was passed in 1907 (Table 4; Runólfsson 1988).

From 1907 through the 1930s, the IFS emphasized the protection of the remaining birch woodlands from livestock grazing and attempted to establish trees by direct seeding (Eysteinsson 2011). The woodlands were an important source of firewood, which was initially a strong motivation for their restoration, although romantic ideas about preservation of the native woodlands also were influential (T. Eysteinsson, personal communication; Fig. 2). However, firewood extraction from the woodlands was limited after fossil fuels, hydropower, and geothermal energy became increasingly available. The catastrophic soil erosion was combated by protecting areas with advancing sand fronts from grazing, constructing sand fences, and seeding native Leymus 
Fig. 2. Average score of main drivers of ecological restoration in Iceland by habitats and periods; I: 1907-1930s, II: 1940s-1960s, III: 1970s-1980s, IV: after 1990.

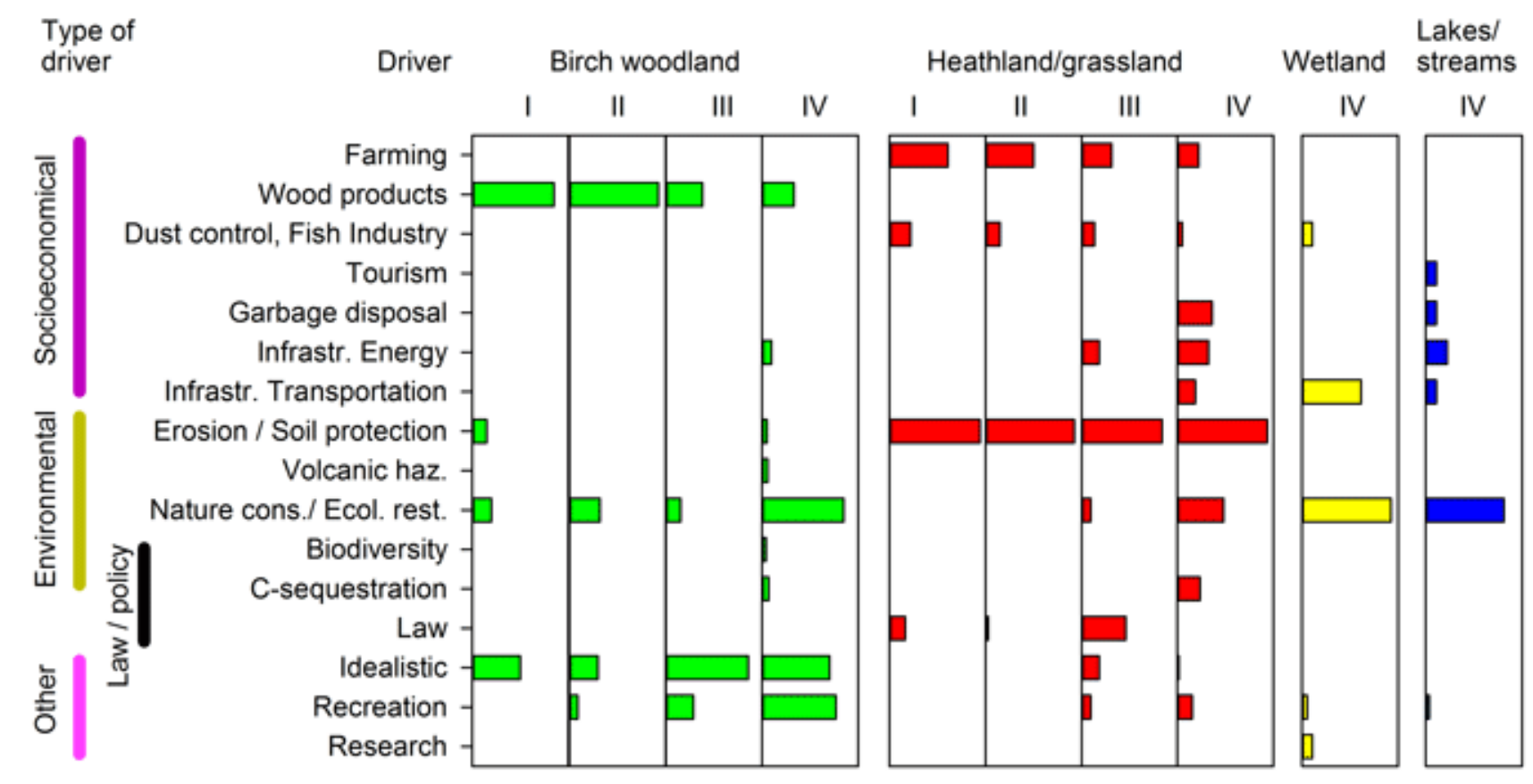

arenarius to stabilize moving sand (Kristmundsson 1958, Halldórsson et al. 2011). Although these actions were mainly motivated by the need to halt sand encroachment and preserve farmland and rangelands (Fig. 2; Runólfsson 1988), many led to ecological restoration of grassland or heathland (Halldórsson et al. 2011). The reduction of dust from soil erosion near some fishing villages was also an incentive for some early soil conservation measures (Kristmundsson 1958).

In the late 1940s and during the 1950s, emphasis in both forestry and soil conservation shifted from being predominantly protection oriented to more production orientation (Magnússon 1997, Eysteinsson 2011). Emphases on cultivation and utilization grew concurrently with agricultural intensification and new technology that allowed for larger scale operations than previously possible (Halldórsson et al. 2011). The IFS increasingly focused on silviculture for timber production, and it put less emphasis on the maintenance and restoration of the native birch woodlands than before (Eysteinsson 2011). Nevertheless, the protection of afforestation areas from livestock grazing promoted the expansion of birch woodlands through natural regeneration in many areas (Aradottir and Eysteinsson 2005).

In the 1950s, there was a rising concern over the growing number of sheep and increased grazing pressure (Sveinsson
1958), resulting in large-scale revegetation to improve land for grazing and hay making (Runólfsson 1988). This work was likely influenced by the large-scale revegetation of the Great Plains of the United States following the Dust Bowl, because there was considerable exchange between the U.S. Soil Conservation Service and the SCSI at this time (Sigurjónsson 1958). As on the Great Plains (Galatowitsch 2012), imported perennial grasses were used for revegetation, and the revegetated areas usually required continued fertilization to maintain productivity (Thorsteinsson 1991). However, a number of successional studies of old revegetation areas have shown that once management with seeding and fertilization was discontinued, their vegetation often developed toward native grassland, heathland, or birch woodland (e.g., Gunnlaugsdóttir 1985, Gretarsdottir et al. 2004). The initial inputs stabilized the soil surface, reduced frost-heaving, and enhanced levels of nutrients and organic matter in the ecosystem, thus accelerating soil formation and colonization by native species (e.g., Gunnlaugsdóttir 1985, Aradóttir 1991, Magnússon 1997).

In the late 1960 s and early 1970 s, there was a growing awareness in Iceland about the past and current treatment of the land and its poor condition compared to past ecological riches. The slogan "to pay the debt to the land" was widely used and Landvernd, an NGO dedicated to reclamation and environmental protection, was established. This stimulated 
Table 4. A summary of potential legal and policy drivers of restoration in Iceland, 1907-2010 (based on Runólfsson 1988, Aradóttir and Pétursdóttir 2011, Crofts 2011).

\begin{tabular}{|c|c|c|}
\hline Year & Title / description & Effects (potential or actual) \\
\hline 1907 & $\begin{array}{l}\text { Act on Forestry and Protection } \\
\text { against Soil Erosion }\end{array}$ & $\begin{array}{l}\text { Stimulated actions to halt sand encroachment and protection of birch woodland remnants, in some } \\
\text { cases leading to woodland restoration and extension. }\end{array}$ \\
\hline 1914 & Act on Land Reclamation & Government could fence off erosion areas to protect them from livestock grazing. \\
\hline 1923 & Sand Reclamation Act & $\begin{array}{l}\text { Formal appointment of a reclamation specialist by the government. Land with active erosion could be } \\
\text { expropriated if owners could not or would not share land reclamation cost. }\end{array}$ \\
\hline 1941 & $\begin{array}{l}\text { Act Concerning Soil Reclamation } \\
\text { and the Prevention of Drifting Sand }\end{array}$ & $\begin{array}{l}\text { The Sand Reclamation Service became an independent governmental institution with increased } \\
\text { control over soil reclamation work. }\end{array}$ \\
\hline 1965 & $\begin{array}{l}\text { Act on Land Reclamation (is still in } \\
\text { force with minor changes) }\end{array}$ & $\begin{array}{l}\text { A major revision of soil conservation law, more emphasis on protection of vegetation and soils, and } \\
\text { sustainable land use than previous law. Formally established the Soil Conservation Service of Iceland. }\end{array}$ \\
\hline 1974 & $\begin{array}{l}\text { A resolution by Parliament regarding } \\
\text { land reclamation and land } \\
\text { conservation commemorating } 1100 \\
\text { years of settlement in Iceland }\end{array}$ & $\begin{array}{l}\text { A substantial increase in funds for vegetation restoration, soil conservation, forestry, and research } \\
\text { over five years (extended twice but with reduced funds). Some of the resulting actions lead to } \\
\text { restoration of native habitats, especially heathlands and birch woodlands, research and growing } \\
\text { number of professionals in the field. }\end{array}$ \\
\hline 1998 & Farming act & $\begin{array}{l}\text { Land improvement should promote sustainable land use and take into account international } \\
\text { commitments regarding conservation of biodiversity. }\end{array}$ \\
\hline 1999 & Act on Nature Conservation & Among objectives is to secure as much as possible of the natural development of Icelandic nature. \\
\hline 1999 & Act on Agricultural Education & Agricultural schools have a role in providing education in protection and restoration of land. \\
\hline 2000 & $\begin{array}{l}\text { Act on Environmental Impact } \\
\text { Assessment (EIA) }\end{array}$ & $\begin{array}{l}\text { Does not mention restoration explicitly, but EIAs are a part of the permission process for construction } \\
\text { projects. In some cases, restoration as mitigation of environmental impacts has been a part of } \\
\text { permission conditions. Large-scale projects, including restoration projects, have to undergo EIA. }\end{array}$ \\
\hline 2000 & $\begin{array}{l}\text { Changes of Act on production, } \\
\text { pricing and trade of agricultural } \\
\text { produce }\end{array}$ & $\begin{array}{l}\text { Enabled 'eco-friendly' subsidies for sheep products, based on rangeland condition, among other } \\
\text { things. Revegetation plans can be a part of cross-compliance for achieving governmental support. }\end{array}$ \\
\hline 2006 & $\begin{array}{l}\text { Act on Regional Afforestation } \\
\text { Programs }\end{array}$ & $\begin{array}{l}\text { Includes afforestation on degraded or eroded land with the aim of improving vegetation cover, soil } \\
\text { quality, and hydrology, thus improving land-use opportunities. So far, only a few landowners have } \\
\text { opted for restoration of birch woodlands within these programs. }\end{array}$ \\
\hline 1994 & Convention on Biodiversity (CBD) & Governmental policy regarding the CBD includes goals of protecting and restoring biodiversity of \\
\hline 2008 & Implementation of CBD in Iceland & Icelandic ecosystems, especially wetland ecosystems and native birch woodlands, and to limit \\
\hline 2010- & $\begin{array}{l}2008 \\
\text { Aichi targets }\end{array}$ & distribution of alien, invasive species. \\
\hline $\begin{array}{l}1994- \\
2002-\end{array}$ & $\begin{array}{l}\text { UNFCCC } \\
\text { The Kyoto protocol }\end{array}$ & $\begin{array}{l}\text { Governmental policy regarding the UNFCCC and the Kyoto protocol includes carbon sequestration in } \\
\text { soils and biomass as one of several means to reduce } \mathrm{CO}_{2} \text { emissions. These include actions of } \\
\text { revegetation, afforestation, and wetland restoration (that can lead to restoration). }\end{array}$ \\
\hline
\end{tabular}

public involvement in land reclamation projects, analogous to the growth in number of community groups focusing on restoration in many other countries from the 1960s to the 1980s (McDonald and Williams 2009, Stewart 2010, Galatowitsch 2012). Discussions in the Icelandic media about the state of the land were also instrumental and included scientists, governmental officials, and influential artists. This awareness was reflected at the governmental level, where a major revision of the soil conservation law was approved in 1965 (see Table 4), placing a new emphasis on soil and vegetation conservation and revegetation of eroded land. A special parliamentary resolution in 1974 to commemorate 1100 years of settlement in Iceland allowed for dramatic increases in funds for revegetation of eroded land and for research focused on land resources (Table 4). This targeted funding, commonly termed "the gift of the nation," resulted in a new focus on vegetation and soil protection and a substantial increase in reclamation work, which involved seeding and fertilization of degraded land (Olgeirsson 2007).

Starting in the 1970s, energy companies became responsible for an increasing number of restoration projects. Revegetation of eroded areas was carried out in relation to the construction of power plants, with the primary aim to halt soil erosion in their vicinity, generate a better environment for their employees, and improve land for grazing (Gunnarsdóttir and Aðalsteinsson 2011). This work continued during the following decades with diverse aims such as to compensate for grazing pastures submerged by reservoirs, to reduce sedimentation from soil erosion into rivers and reservoirs, to enhance environmental quality near power plants, and to restore land damaged by construction and gravel mines (Friðriksdóttir and Hjartarson 2011, Gunnarsdóttir and Aðalsteinsson 2011). Some of these were mandatory compensation or mitigation actions (cf. Suding 2011); others were voluntary and/or a part of agreements between the power companies and local farmers and other land users. These restoration projects commonly addressed environmental problems that were not directly connected to the construction project in question, which might indicate efforts to demonstrate corporate goodwill or social responsibility (cf. McGhee et al. 2007). 
The diversity of drivers for ecological restoration increased after 1990 (Fig. 2), as did the diversity of goals and approaches to restoration and soil conservation. Wetland restoration was predominantly motivated by nature conservation, but mitigation to offset damage to wetlands caused by road construction (cf. Mitsch et al. 1998) was also a driver (Stefánsdóttir 2011). Landowners were increasingly involved in revegetation, especially after the launch of the Farmers Heal the Land (FHL) program. SCSI's motivations for establishing FHL were to increase farmers' responsibility in taking care of the land, to increase their initiative and participation in the conservation process, and to build mutual trust between farmers and the agency (Arnalds 2005). A survey of FHL participants in 1999 (Schmidt 2000) showed that moral values such as improved aesthetics of the countryside and a wish to deliver the land in better condition to the next generation, together with environmental concerns, were important motivations for their participation in the project. Potential benefits of improved grazing management and direct financial benefits did not weigh as much, even though most of the participating FHL farmers used the reclaimed land for grazing (Schmidt 2000). Later studies have confirmed that idealistic or moral values are important drivers for farmers participating in FHL (Petursdottir et al. 2013).

International policy is increasingly becoming a driver for ecological restoration (see e.g., Bullock et al. 2011). Climate change strategies of the Icelandic government have included carbon sequestration in vegetation and soil (Icelandic Ministry for the Environment 2007), which has become one of the justifications for governmentally funded restoration and afforestation programs. Industry has increasingly supported restoration for the same purpose. Currently, there is a growing interest in curbing the immense release of greenhouse gases from drained wetlands through wetland restoration, as the rewetting of land with organic soil may become eligible as a mitigation action under the UNFCCC (2011).

The main motivation of the Hekluskógar project, initiated in 2007, was to increase the resilience of ecosystems near Mt. Hekla to impacts of volcanic ash from frequent eruptions in the volcano (Aradottir 2007, Óskarsson 2011a). This especially applies to secondary distribution of ash by wind and water, which can cause land degradation and soil erosion (Thorarinsdottir and Arnalds 2012). Thus, the Hekluskógar project exemplifies restoration to reduce adverse ecosystem degradation under likely disturbances (cf. Mori 2011, Suding 2011).

\section{Socioeconomic and environmental motivations for ecological restoration}

Motivations for restoration actions are often pragmatic and aim at restoring natural capital and ecosystem services (cf. Clewell and Aronson 2006, Suding 2011). This was often the case in Iceland, where the protection of woodland and soil resources, reversal of land degradation, increased forest or rangeland productivity and provision of other ecological services, especially amelioration of climate change, were common drivers for restoration. Restoration in relation to construction increased after 1970 and especially after 1990, coinciding with growth of the energy sector and road construction. On the other hand, the conservation of biodiversity, per se, hardly showed up as a driver for restoration in our analysis (Fig. 2) and our review yielded only two examples of preservation of rare or endangered populations. This separates Iceland from most other European countries, where biodiversity concerns are important motivators of ecological restoration (Madgwick and Jones 2002). A possible reason for this is the immense scale of the degradation in Iceland, and the importance of restoration actions as a response to the environmental threat of catastrophic soil erosion (Magnússon 1997). The importance of soil erosion as an environmental motivator for ecological restoration is more akin to emphasis in the Loess Plateau in China (Chen et al. 2007, Fu et al. 2010) and the drier parts of the USA and South America (e.g., Imeson 2012). As a consequence, restoration objectives in Iceland have often been rather vague and focus more on functionality, e.g., halting soil erosion or restoring soil fertility, and broad ecosystem structure such as birch woodland and heathland, rather than aiming at specific community types or historical fidelity.

\section{Financial and policy mechanisms affecting ecological restoration}

Financial incentives can be strong drivers for restoration (de Groot et al. 2007). In essence, the majority of ecological restoration projects and programs in Iceland have been funded by the government in one way or another (Arnalds 2005). In our study, funding was never identified as one of the three most important drivers for a restoration project (Fig. 2), but it is probably more important than our results indicate. For example, laws and policies were primarily identified as drivers when they resulted in special funding efforts, such as the "gift of the nation" or designated programs to stimulate carbon sequestration. The large scale Farmers Heal the Land program is an example of a project funded by the government, which would most likely not be active without this funding. The same applies to the Hekluskógar project, which did not commence until substantial governmental funding was secured.

In contrast to the EU, where policies such as the habitat directive, the bird directive, Natura 2000 networks, and the EU-LIFE Nature financial instrument provide strong mechanisms for ecological restoration (Madgwick and Jones 2002), Iceland has relatively weak policy instruments for restoration (Aradóttir and Pétursdóttir 2011). The current acts on forestry and soil conservation are from 1955 and 1965 , respectively, and are in many ways outdated. These acts did not show up as influential in our analysis although they form the bases for the work of IFS and SCSI, the agencies 
responsible for most ecological restoration work in Iceland. Several other acts in Icelandic law touch upon subjects that can be interpreted as legal stimulus to restore degraded land (Table 4), but none of them explicitly mention ecological restoration (Aradóttir and Pétursdóttir 2011). This might be changing as recent governmental strategy papers relating to sustainable development and the implementation of the 2020 Aichi targets (http://www.cbd.int/doc/strategic-plan/2011-2020/ Aichi-Targets-EN.pdf) include ecological restoration (e.g., Icelandic Ministry for the Environment 2008).

Iceland has some policy mechanisms that may hinder or compete with ecological restoration. For example, regional afforestation programs offer substantial financial incentives for afforestation that is mostly based on the planting of introduced tree species (Eysteinsson 2004). This practice is fortified by Icelandic tax authorities that in most cases do not recognize native forestry as a commercial enterprise qualifying for VAT refunds (Aradóttir and Petursdóttir 2011). Afforestation programs that encourage the establishment of alien over native forests are not unique to Iceland, but they can negatively affect the potential for ecosystem restoration and result in a net biodiversity loss (Marais et al. 2007, Lindenmayer et al. 2012). Governmental subsidies for sheep farming in Iceland pose another example of "perverse incentives" to ecological restoration (cf. Schuyt 2005). The poor state of communal rangelands in Iceland is mostly related to continuous grazing of sheep (Thorsteinsson et al. 1971). Nevertheless, subsidies of the sheep farming have had limited consideration of the state of the land, thus maintaining poor land condition in large areas (Arnalds and Barkarson 2003). In recent years, there have been some financial incentives to improve grazing land under the auspices of quality measures that have stimulated revegetation of private land and highland commons (Arnalds 2005, Crofts 2011).

\section{Other potential drivers of ecological restoration}

At the beginning of the 20th century, the Icelandic population was predominantly rural, and most people had limited means to provide for other than basic necessities (Karlsson 2000). Iceland was under Danish rule, but gained home rule in 1904. At that time there was a general wish for progress, and awakening of national values with an emphasis on the land (Kristmundsson 1958). For example, one mission of the Icelandic Youth Association, founded in 1907, was to "protect the country's natural environment and to heal the wounds which have been caused by the interaction of the land and the nation" (http://www.umfi.is/umfi09/veftre/umfi/um_umfi/). Like the slogan "to pay the debt to the land," this represents an example of both an idealistic and romantic motivation for restoration and is related to the "undertaking of restoration as atonement for environmental damage" (cf. Clewell and Aronson 2006). Such idealistic rationales for restoration may also relate to the love of the land or a wish to connect with nature (e.g., Jordan 2003, Clewell and Aronson 2006), as was seen in both the "romantic" notions in woodland restoration, and the wishes of the FHL farmers to improve the aesthetics of the countryside and deliver the land in better condition to the next generation.

Migration from rural to urban areas may offer opportunities for ecological restoration (McGhee et al. 2007, Wang et al. 2011). During the 20th century, the population of Iceland changed from being predominantly rural to predominantly urban, and the population of rural areas decreased from about 60,000 to about 20,000 (FAI 2009). A growing number of the rural inhabitants do not make their primary living from traditional agriculture. After the intensification of the sheep farming during most of the 20th century, sheep numbers decreased by nearly half in the 1980s (Jónsson and Magnússon 1997, FAI 2009). Hence, grazing pressure by sheep has been reduced in many areas, and some have been completely protected from grazing. These changes in demography and land use have created opportunities for both intended and unintended restoration, but their extent has not been documented. However, the free-roaming grazing systems used in Iceland (Arnalds and Barkarson 2003) limit the potential effects of this shift.

It has been argued that scientific advancements (technological drivers) and a strong conceptual basis are essential for progress in restoration (Hobbs and Harris 2001, Galatowitsch 2012); especially because restoration actions are often implemented before adequate field tests of methods (Palmer 2009). Toward the end of the 20th century, coinciding with the development of Restoration Ecology as a discipline, restoration research activity in Iceland increased markedly (Fig. 1), as did the number of scientists working in this field (Crofts 2011). Revegetation techniques and selection of grass species and varieties, mostly imported, were the main focus of early restoration research. Later on, the focus shifted to a greater variety of methods and native species, along with research on the trajectories and mechanisms of ecological succession and restoration of ecosystem services following restoration interventions. Although our analysis did not elucidate research or technological development as a major driver of restoration, they have at least influenced the objectives of restoration projects and have stimulated new approaches to restoration. For example, the inclusion of carbon sequestration in vegetation and soils in the climate change strategies of the Icelandic government was in part based on research showing significant carbon sequestration by afforestation (Snorrason et al. 2002) and by revegetation of eroded areas (Aradóttir et al. 2000, Arnalds et al. 2000).

\section{CONCLUSIONS}

Our results show that although the diversity of drivers for ecological restoration in Iceland increased markedly over time, some main drivers were important over most of the last century. In terms of area, halting of soil erosion and protection 
of soils and vegetation were the strongest drivers, which reflects the immense scale of the degradation and the importance of restoration actions as a response to the environmental threat of soil erosion. Idealistic or moral values were also important motivations of restoration interventions throughout the period.

Socioeconomic drivers such as farming and the provision of wood products motivated restoration over most of the 20th century. However, their relative importance decreased toward the end of the century. This coincided with changes in grazing pressure and land use associated with a demographic shift from rural to urban areas and a reduction in the number of sheep. Growth of the energy sector and the transportation infrastructure also contributed to the change in drivers, although the specified rationales for restoration were diverse, ranging from erosion control and mitigation actions to demonstrations of corporate goodwill. In the 1990s, climate change mitigation emerged as a driver and the importance of nature conservation and recreation increased, which reflects an increased emphasis on environmental issues in the postRio era as well as lifestyle changes of an increasingly urban population.

Our study did not reveal technological or scientific advancements, or financial incentives or policies as important drivers of ecological restoration in Iceland. Nevertheless, there are some indications that these factors can indirectly motivate ecological restoration and affect its objectives and approaches; however, different methods are needed to assess their importance. We propose that the main reason for the low importance of policy as a driver is the weak and outdated law and policy framework for ecological restoration in Iceland. It is urgent to strengthen and update the policy framework so that it is more in tune with current environmental paradigms, scientific knowledge, and international development. Such an update should also address "perverse incentives" that hinder restoration or pose a threat to biodiversity, including subsidies to farmers utilizing severely degraded land and subsidies for afforestation with exotic tree species.

Responses to this article can be read online at: http://www.ecologyandsociety.org/issues/responses. $\mathrm{php} / 5946$

\section{Acknowledgments:}

We thank all those who contributed to the review of this paper, and the Nordic Council of Ministers for financial support. Finally, we thank two anonymous reviewers for constructive comments on an earlier version of the manuscript.

\section{LITERATURE CITED}

Amorosi, T., P. Buckland, A. Dugmore, J. H. Ingimundarson, and T. H. McGovern. 1997. Raiding the landscape: human impact in the Scandinavian North Atlantic. Human Ecology 25:491-518. http://dx.doi.org/10.1023/A:1021879727837

Aradóttir, Á. L. 1991. Population biology and stand development of birch (Betula pubescens Ehrh.) on disturbed sites in Iceland. Dissertation. Department of Range Science, Texas A \& M University, College Station, Texas, USA.

Aradottir, A. L. 2007. Restoration of birch and willow woodland on eroded areas. Pages 67-74 in G. Halldorsson, E. S. Oddsdottir, and O. Eggertsson, editors. Effects of afforestation on ecosystems, landscape and rural development. Proceedings of the AFFORNORD conference. TemaNord 2007:508, Reykholt, Iceland, June 18-22, 2005. [online] URL: http://www.norden.org/en/publications/ publikationer/2007-508

Aradottir, A. L., and O. Arnalds. 2001. Ecosystem degradation and restoration of birch woodlands in Iceland. Pages 295-308 in F. E. Wielgolaski, editor. Nordic mountain birch ecosystems. UNESCO, Paris, France, and Parthenon, Carnforth, UK.

Aradottir, Á. L., and T. Eysteinsson. 2005. Restoration of birch woodlands in Iceland. Pages 195-209 in J. A. Stanturf and P. Madsen, editors. Restoration of boreal and temperate forests. CRC, Boca Raton, Florida, USA.

Aradóttir, Á. L., and G. Halldórsson, editors. 2011. Vistheimt á Íslandi [Ecological restoration in Iceland]. Landbúnaðarháskóli Íslands og Landgræðsla ríkisins, Reykjavík, Iceland. [online] URL: http://pdfvef.oddi.is/landgraedslan/vistheimt a islandi/

Aradóttir, Á. L., G. Halldórsson, K. Svavarsdóttir, and Ó. Arnalds. 2011. Vistheimtarrannsóknir - yfirlit [Ecological restoration research in Iceland - review]. Pages 112-127 in Á. L. Aradóttir and G. Halldórsson, editors. Vistheimt á Íslandi [Ecological restoration in Iceland]. Landbúnaðarháskóli Íslands og Landgræðsla ríkisins, Reykjavík, Iceland.

Aradóttir, Á. L., and P. Pétursdóttir. 2011. Opinber stefnumótun og stjórnsýsluhvatar er varða vistheimt á Íslandi [Policies and incentives for ecological restoration in Iceland]. Pages 24-30 in Á. L. Aradóttir and G. Halldórsson, editors. Vistheimt á Íslandi [Ecological restoration in Iceland]. Landbúnaðarháskóli Íslands og Landgræðsla ríkisins, Reykjavík, Iceland.

Aradóttir, Á. L., K. Svavarsdóttir, T. H. Jónsson, and G. Guðbergsson. 2000. Carbon accumulation in vegetation and soils by reclamation of degraded areas. Icelandic Agricultural Sciences 13:99-113.

Arnalds, A. 2005. Approaches to landcare - a century of soil conservation in Iceland. Land Degradation \& Development 16:113-125. http://dx.doi.org/10.1002/ldr.665 
Arnalds, O. 2008. Soils of Iceland. Jökull 58:409-421.

Arnalds, Ó. 2011. Náttúrufar [Physiography]. Pages 14-18 in Á. L. Aradóttir and G. Halldórsson, editors. Vistheimt á Íslandi [Ecological restoration in Iceland]. Landbúnaðarháskóli Íslands og Landgræðsla ríkisins, Reykjavík, Iceland.

Arnalds, O., and B. H. Barkarson. 2003. Soil erosion and land use policy in Iceland in relation to sheep grazing and government subsidies. Environmental Science \& Policy 6:105-113. http://dx.doi.org/10.1016/S1462-9011(02)00115-6

Arnalds, Ó., G. Guðbergsson, and J. Guðmundsson. 2000. Carbon sequestration and reclamation of severely degraded soils in Iceland. Icelandic Agricultural Sciences 13:87-97.

Arnalds, Ó., E. F. Porarinsdóttir, S. Metusalemsson, A. Jonsson, E. Gretarsson, and A. Arnason. 2001. Soil erosion in Iceland. The Soil Conservation Service and the Agricultural Research Institute, Reykjavík, Iceland. [online] URL: http:// www.rala.is/desert/Soil\%20Erosion.pdf

Bullock, J. M., J. Aronson, A. C. Newton, R. F. Pywell, and J. M. Rey-Benayas. 2011. Restoration of ecosystem services and biodiversity: conflicts and opportunities. Trends in Ecology \& Evolution 26:541-549. http://dx.doi.org/10.1016/ j.tree.2011.06.011

Chen, L., W. Wei, B. Fu, and Y. Lu. 2007. Soil and water conservation on the Loess Plateau in China: review and perspective. Progress in Physical Geography 31:389-403. http://dx.doi.org/10.1177/0309133307081290

Clewell, A. F., and J. Aronson. 2006. Motivations for the restoration of ecosystems. Conservation Biology 20:420-428. http://dx.doi.org/10.1111/j.1523-1739.2006.00340.x

Crofts, R. 2011. Healing the land: the story ofland reclamation and soil conservation in Iceland. Soil Conservation Service of Iceland, Gunnarsholt, Iceland.

de Groot, R., M. de Wit, E. J. Brown Gaddis, C. Kousky, W. McGhee, and M. D. Young. 2007. Making restoration work: financial mechanisms. Pages 286-293 in J. Aronson, S. J. Milton, and J. N. Blignaut, editors. Restoring natural capital: science, business, and practice. Island Press, Washington, D. C., USA.

Dugmore, A. J., G. Gísladóttir, I. A. Simpson, and A. Newton. 2009. Conceptual models of 1200 years of Icelandic soil erosion reconstructed using tephrochronology. Journal of the North Atlantic 2:1-18. http://dx.doi.org/10.3721/037.002.0103

Eysteinsson, T. 2004. Forestry in a treeless land. Lustgården 84:27-34.

Eysteinsson, T. 2011. Vistheimt á vegum Skógræktar ríkisins [Ecological restoration by the Icelandic Forest Service]. Pages 49-51 in Á. L. Aradóttir and G. Halldórsson, editors. Vistheimt á Íslandi [Ecological restoration in Iceland]. Landbúnaðarháskóli Íslands og Landgræðsla ríkisins, Reykjavík, Iceland.

Farmers Association of Iceland (FAI). 2009. Icelandic agricultural statistics 2009. The Farmers Association of Iceland, Reykjavík, Iceland. [online] URL: http://bondi.is/ $\underline{\text { lisalib/getfile.aspx? } \text { itemid }=2211}$

Friðriksdóttir, H., and G. Hjartarson. 2011. Vistheimt á vegum Orkuveitu Reykjavíkur [Ecological restoration by the Reykjavík Energy Company]. Pages 64-66 in Á. L. Aradóttir and G. Halldórsson, editors. Vistheimt á Íslandi [Ecological restoration in Iceland]. Landbúnaðarháskóli Íslands og Landgræðsla ríkisins, Reykjavík, Iceland.

Fu, B., D. Niu, Y. Lu, G. Liu, and W. Zhao. 2010. Land degradation and ecological restoration in China. Pages 140-174 in F. A. Comín, editor. Ecological restoration: a global challenge. Cambridge University Press, Cambridge, UK.

Galatowitsch, S. M. 2012. Ecological restoration. Sinauer Associates, Sunderland, Massachusetts, USA.

Garðarsson, A., B. Magnússon, E. Ó Thorleifsson, H. Óskarsson, J. Ó. Hilmarsson, N. Á. Lund, S. Thráinsson, and T. Baldursson. 2006. Endurheimt votlendis 1996-2006. Skýrsla Votlendisnefndar [Wetland restoration in Iceland 1996-2006]. Ritstjóri Daníel Bergmann. Landbúnaðarráđuneytið, Reykjavík, Iceland. [online] URL:http://www.sjavarutvegsraduneyti. is/media/Skyrslur/votlendisskyrsla.pdf

Gísladóttir, G., E. Erlendsson, R. Lal, and J. Bigham. 2010. Erosional effects on terrestrial resources over the last millennium in Reykjanes, southwest Iceland. Quaternary Research 73:20-32. http://dx.doi.org/10.1016/j.yqres.2009.09.007

Greipsson, S. 2012. Catastrophic soil erosion in Iceland: impact of long-term climate change, compounded natural disturbances and human driven land-use changes. CATENA 98:41-54. http://dx.doi.org/10.1016/j.catena.2012.05.015

Gretarsdottir, J., A. L. Aradottir, V. Vandvik, E. Heegaard, and H. J. B. Birks. 2004. Long-term effects of reclamation treatments on plant succession in Iceland. Restoration Ecology 12:268-278. http://dx.doi.org/10.1111/j.1061-2971.2004.00371. $\underline{\mathrm{X}}$

Gunnarsdóttir, H., and H. Aðalsteinsson. 2011. Vistheimt á vegum Landsvirkjunar [Ecological restoration by Landsvirkjun]. Pages 60-63 in Á. L. Aradóttir and G. Halldórsson, editors. Vistheimt á Íslandi [Ecological restoration in Iceland]. Landbúnaðarháskóli Íslands og Landgræðsla ríkisins, Reykjavík, Iceland.

Gunnlaugsdóttir, E. 1985. Composition and dynamical status of heathland communities in Iceland in relation to recovery measures. Acta Phytogeographica Suecica 75:1-84. 
Halldórsson, G., Á. L. Aradóttir, A. M. Fosaa, D. Hagen, C. Nilsson, K. Raulund-Rasmussen, A. B. Skrindo, K. Svavarsdóttir, and A. Tolvanen. 2012. ReNo. Restoration of damaged ecosystems in the Nordic countries. TemaNord 2012:558. http://dx.doi.org/10.6027/TN2012-558

Halldórsson, G., K. Svavarsdóttir, E. F. Thorarinsdóttir, and S. Runólfsson. 2011. Vistheimt á vegum Landgræðslu ríkisins [Ecological restoration by the Soil Conservation Service of Iceland]. Pages 40-48 in Á. L. Aradóttir and G. Halldórsson, editors. Vistheimt á Íslandi [Ecological restoration in Iceland]. Landbúnaðarháskóli Íslands og Landgræðsla ríkisins, Reykjavík, Iceland.

Hallsdóttir, B. S., K. Harðardóttir, J. Guðmundsson, A. Snorrason, and J. Thórsson. 2010. Emissions of greenhouse gases in Iceland from 1990 to 2008. National Inventory Report 2010. Submitted under the United Nations Framework Convention on Climate Change and the Kyoto Protocol. Umhverfisstofnun, UST-2020:05. Environment Agency of Iceland, Reykjavík, Iceland. [online] URL: http://groa.rala. is/Kortavefsja/ICELAND NIR 2010.pdf

Hobbs, R. J., and J. A. Harris. 2001. Restoration ecology: repairing the Earth's ecosystems in the new millennium. Restoration Ecology 9:239-246. http://dx.doi.org/10.1046/ j.1526-100x.2001.009002239.x

Hobbs, R. J., and D. A. Norton. 1996. Towards a conceptual framework for restoration ecology. Restoration Ecology 4:93-110. http://dx.doi.org/10.1111/j.1526-100X.1996.tb00112. $\underline{\mathrm{x}}$

Icelandic Ministry for the Environment. 2007. Iceland's climate change strategy. Icelandic Ministry for the Environment, Reykjavík, Iceland. [online] URL: http://eng. umhverfisraduneyti.is/media/PDF_skrar/Stefnumorkun_i_loftslagsmalum enlokagerd.pdf

Icelandic Ministry for the Environment. 2008. Líffræðileg fjölbreytni. Stefnumörkun Íslands um framkvæmd Samningsins um líffræðilega fjölbreytni [Biodiversity. Policy Strategy for Iceland in relation to the UN Convention on Biodiversity (CBD)]. Icelandic Ministry for the Environment, Reykjavík, Iceland. [online] URL: http://www.umhverfisraduneyti.is/ $\underline{\text { media/PDF_skrar/liffjolbreytni.pdf }}$

Iceland Road Administration (ICERA). 2012. The road system 2012. Icelandic Road Administration (ICERA), Reykjavík, Iceland. [online] URL: http://www.vegagerdin.is/vefur2.nsf/ Files/RoadSystem2012/\$file/RoadSystem2012.pdf

Imeson, A. 2012. Desertification, land degradation and sustainability. Paradigms, processes, principles and policies. Wiley-Blackwell, Chichester, UK. http://dx.doi. org/10.1002/9781119977759
Jónsson, B. G. 2011. Gróđur fyrir fólk í Landnámi Ingólfs [Restoration by GFF, an NGO]. Pages 67-70 in Á. L. Aradóttir and G. Halldórsson, editors. Vistheimt á Íslandi [Ecological restoration in Iceland]. Landbúnaðarháskóli Íslands og Landgræðsla ríkisins, Reykjavík, Iceland.

Jónsson, G., and M. S. Magnússon, editors. 1997. Hagskinna [Icelandic Historical Statistics]. Statistics Iceland, Reykjavík, Iceland.

Jordan, R. 2003. The Sunflower forest: ecological restoration and the new communion with nature. University of California Press, Berkeley, California, USA.

Karlsson, G. 2000. Iceland's 1100 years. The history of a marginal society. Hurst \& Company, London, UK.

Kristmundsson, G. 1958. Upphaf skipulagsbundinnar sandgræðslu [The beginning of organized soil conservation activities in Iceland]. Pages 187-249 in A. Sigurjónsson, editor. Sandgraðslan [Fifty years of soil conservation in Iceland]. Agricultural Society of Iceland and Soil Conservation Service of Iceland, Gunnarsholt, Iceland.

Lindenmayer, D. B., K. B. Hulvey, R. J. Hobbs, M. Colyvan, A. Felton, H. Possingham, W. Steffen, K. Wilson, K. Youngentob, and P. Gibbons. 2012. Avoiding bio-perversity from carbon sequestration solutions. Conservation Letters 5:28-36. http://dx.doi.org/10.1111/j.1755-263X.2011.00213. $\underline{\mathrm{X}}$

Madgwick, F. J., and A. T. Jones. 2002. Europe. Pages 32-56 in M. R. Perrow and A. J. Davy, editors. Handbook of ecological restoration. Volume 2. Restoration in practice. Cambridge University Press, Cambridge, UK.

Magnússon, S. H. 1997. Restoration of eroded areas in Iceland. Pages 188-211 in K. M. Urbanska, N. R. Webb, and P. J. Edwards, editors. Restoration ecology and sustainable development. Cambridge University Press, Cambridge, UK.

Marais, C., P. Woodworth, M. De Wit, J. Craig, K. D. Holl, and J. Gouza. 2007. Overcoming socioeconomic obstacles to restore natural capital. Pages 256-264 in J. Aronson, S. J. Milton, and J. N. Blignaut, editors. Restoring natural capital: science, business, and practice. Island Press, Washington, D. C., USA.

McDonald, T., and J. Williams. 2009. A perspective on the evolving science and practice of ecological restoration in Australia. Ecological Management \& Restoration 10:113-125. http://dx.doi.org/10.1111/j.1442-8903.2009.00472.x

McGhee, W., J. Craig, R. de Groot, J. S. Miller, and K. Bowers. 2007. Making restoration work: nonmonetary mechanisms. Pages 294-302 in J. Aronson, S. J. Milton, and J. N. Blignaut, 
editors. Restoring natural capital: science, business, and practice. Island Press, Washington, D.C., USA.

Mitsch, W. J., X. Wu, R. W. Nairn, P. E. Weihe, N. Wang, R. Deal, and C. E. Boucher. 1998. Creating and restoring wetlands: a whole-ecosystem experiment in self-design. BioScience 48:1019-1030. http://dx.doi.org/10.2307/1313458

Mori, A. S. 2011. Ecosystem management based on natural disturbances: hierarchical context and non-equilibrium paradigm. Journal of Applied Ecology 48:280-292. http://dx. doi.org/10.1111/j.1365-2664.2010.01956.x

Olgeirsson, F. G. 2007. Sáðmenn sandanna. Saga landgraæðslu á Íslandi 1907-2007 [The story of ecological restoration in Iceland 1907-2007]. Soil Conservation Service of Iceland, Gunnarsholt, Iceland.

Óskarsson, H. 1998. Framræsla votlendis á Vesturlandi [Wetland drainage in West Iceland]. Pages 121-129 in J. S. Ólafsson, editor. Íslensk votlendi, verndun og nýting [Wetlands in Iceland, protection and utilization]. Háskólaútgáfan, Reykjavík, Iceland.

Óskarsson, H. 2011a. Hekluskógar. Pages 71-74 in Á. L. Aradóttir and G. Halldórsson, editors. Vistheimt á Íslandi [Ecological restoration in Iceland]. Landbúnaðarháskóli Íslands og Landgræðsla ríkisins, Reykjavík, Iceland.

Óskarsson, H. 2011b. Vistheimt á vegum Votlendisnefndar. Pages 54-55 in Á. L. Aradóttir and G. Halldórsson, editors. Vistheimt á Íslandi [Ecological restoration in Iceland]. Landbúnaðarháskóli Íslands og Landgræðsla ríkisins, Reykjavík, Iceland.

Óskarsson, H., Ó. Arnalds, J. Gudmundsson, and G. Gudbergsson. 2004. Organic carbon in Icelandic Andosols: geographical variation and impact of erosion. CATENA 56:225-238. http://dx.doi.org/10.1016/j.catena.2003.10.013

Palmer, M. A. 2009. Reforming watershed restoration: science in need of application and applications in need of science. Estuaries and Coasts 32:1-17. http://dx.doi.org/10.1007/ $\underline{\text { s12237-008-9129-5 }}$

Pétursdóttir, T. 2011. Bændur græða landið - samstarf um uppgræðslu og endurheimt vistkerfa [Farmers Heal the Land a cost share program on revegetaion and restoration of ecosystems]. Pages 84-85 in Á. L. Aradóttir and G. Halldórsson, editors. Vistheimt á Íslandi [Restoration in Iceland]. Landbúnaðarháskóli Íslands og Landgræðsla ríkisins, Reykjavík, Iceland.

Petursdottir, T., O. Arnalds, S. Baker, L. Montanarella, and Á. Aradóttir. 2013. A social-ecological system approach to analyze stakeholders' interactions within a large-scale rangeland restoration program. Ecology and Society 18(2): 29. http://dx.doi.org/10.5751/ES-05399-180229

Runólfsson, S. 1988. Landgræðslan í 80 ár 1907-1987 [Eighty years of Soil Conservation Service of Iceland in 1907-1987]. Græðum Ísland: Árbók Landgræðslunnar I:99-124.

Runólfsson, S., E. F. Thórarinsdóttir, Á. L. Aradóttir, and K. Svavarsdóttir. 2009. Skógeyjarsvæðið - endurheimt votlendis úr sandi [Skógey - wetland restoration]. Fraæðaping landbúnaðarins 6:259-264.

Schmidt, G. 2000. Bændur græða landið - viðhorf bænda [Farmers Heal the Land - farmers perspectives]. Rádunautafundur 2000:93-98.

Schuyt, K. 2005. Perverse policy incentives. Pages 78-83 in S. Mansourian, D. Vallauri, N. Dudley (with WWF International), editors. Forest restoration in landscapes. Beyond planting trees. Springer, New York, New York, USA.

Sigurjónsson, A., editor. 1958. Sandgraeðslan [Fifty years of soil conservation in Iceland]. Agricultural Society of Iceland and Soil Conservation Service of Iceland, Gunnarsholt, Iceland.

Skarphéðinsson, K. H. 2011. Restoration of the Icelandic Sea Eagle population. Pages 18-21 in G. Halldórsson, editor. Restoring the North - challenges and opportunities. International Restoration Conference, Selfoss, Iceland, October 20-22, 2011. Book of abstracts. Soil Conservation Service of Iceland and Agricultural University of Iceland, Reykjavík, Iceland.

Snorrason, A., B. D. Sigurðsson, G. Guðbergsson, K. Svavarsdóttir, and T. H. Jónsson. 2002. Carbon sequestration in forest plantations in Iceland. Icelandic Agricultural Sciences 15:81-93.

Society for Ecological Restoration International Science \& Policy Working Group (SER). 2004. The SER international primer on ecological restoration. SER, Washington, D.C., USA. [online] URL: http://www.ser.org/docs/defaultdocument-library/english.pdf

Stefánsdóttir, M. B. 2011. Vistheimt á vegum Vegagerðarinnar [Ecological restoration by the Icelandic Road Administration]. Pages 56-59 in Á. L. Aradóttir and G. Halldórsson, editors. Vistheimt á Íslandi [Ecological restoration in Iceland]. Landbúnaðarháskóli Íslands og Landgræðsla ríkisins, Reykjavík, Iceland.

Stewart, M. J. 2010. Does the past matter in Scottish woodland restoration? Pages 63-73 in M. Hall, editor. Restoration and history: the search for a usable environmental past. Routledge, New York, New York, USA. 
Suding, K. N. 2011. Toward an era of restoration in ecology: successes, failures, and opportunities ahead. Annual Review of Ecology, Evolution, and Systematics 42:465-487. http://dx. doi.org/10.1146/annurev-ecolsys-102710-145115

Sveinsson, P. 1958. Sandgræðslumálin á líðandi stund [Current issues on revegetation in Iceland]. Pages 291-311 in A. Sigurjónsson, editor. Sandgrceðslan [Fifty years of soil conservation in Iceland]. Agricultural Society of Iceland and Soil Conservation Service of Iceland, Gunnarsholt, Iceland.

Thorarinsdottir, E. F., and O. Arnalds. 2012. Wind erosion of volcanic materials in the Hekla area, South Iceland. Aeolian Research 4:39-50. http://dx.doi.org/10.1016/j.aeolia.2011.12.006

Thordarson, T., and A. Höskuldsson. 2008. Postglacial volcanism in Iceland. Jökull 58:197-228.

Thórsson, B. 2011. Vistheimt á vegum Norðurlandsskóga [Ecological restoration by the North Iceland Afforestation Program]. Pages 52-53 in Á. L. Aradóttir and G. Halldórsson, editors. Vistheimt á Íslandi [Ecological restoration in Iceland]. Landbúnaðarháskóli Íslands og Landgræðsla ríkisins, Reykjavík, Iceland.

Thorsteinsson, I. 1991. Uppgraæsla á Auðkúluheiði og Eyvindarstaðaheiði 1981-1989 [Revegetation on Auðkúluheiði and Eyvindarstaðaheiði heathlands in 1981-1989]. Agricultural Research Institute, Reykjavík, Iceland.

Thorsteinsson, I., G. Olafsson, and G. M. van Dyne. 1971. Range resources of Iceland. Journal of Range Management 24:86-93.

Turpie, J. K., C. Marais, and J. N. Blignaut. 2008. The working for water programme: evolution of a payments for ecosystem services mechanism that addresses both poverty and ecosystem service delivery in South Africa. Ecological Economics 65:788-798. http://dx.doi.org/10.1016/j.

ecolecon.2007.12.024

United Nations Framework Convention on Climate Change (UNFCCC). 2011. Consideration of further commitments for Annex I parties under the Kyoto Protocol. UNFCC, Durban, South Africa. [online] URL: http://unfccc.int/resource/ docs/2011/awg16/eng/103a02.pdf

Wang, C., Y. Yang, and Y. Zhang. 2011. Economic development, rural livelihoods, and ecological restoration: evidence from China. Ambio 40:78-87. http://dx.doi. org/10.1007/s13280-010-0093-5 